\title{
A Comparison of Standard Practice Treatments in Research Library Book Conservation, 2007 to 2017
}

\section{Whitney S. Baker}

In 2007, a web-based survey of book conservation practices was conducted to document standard-practice, moderate-use, and low-use book conservation treatments for general and special collections in research libraries in the United States. This paper reports on the findings of a ten-year follow-up survey conducted in 2017 to determine whether and how book conservation treatment practices have changed over the last ten years. Overall, the data indicate that while general collections treatment practices have remained consistent, special collections practices continue to evolve, with many treatments newly qualifying as standard practice in the special collections context since 2007. The data also suggest areas of further research, including how demographic factors may correlate with particular treatment practices.

Whitney S. Baker (wbaker@ku.edu) is Head, Conservation Services, University of Kansas Libraries

Manuscript submitted April 10, 2018; returned to author for minor revision August 3, 2018; revised manuscript submitted August 8, 2018; accepted for publication September 24, 2018.

The author would like to thank and recognize Liz Dube for fruitful collaboration on the analysis, research, and publication of the 2007 data, and her assistance in preparing and disseminating the 2017 survey that resulted in this analysis.
T n 2007, a survey was conducted among conservation practitioners, resulting 1 in a published assessment of book conservation practices in research libraries in the United States. ${ }^{1}$ This research identified a "standard toolbox" of treatments for both general and special collections as practiced in the first decade of the twenty-first century, establishing a baseline for subsequent comparisons. It provided a quantitative synopsis of how book conservation was actually practiced in research libraries as compared to what was documented in the literature. A second publication correlated institutional context and training of conservation professionals with specific treatment practices. ${ }^{2}$ The second study concluded that practitioners working in hybrid facilities - in which both general and special collections were treated - tended to use a hybrid treatment approach, straddling more traditionally general versus special collections treatment practices.

This study reports on the findings of a ten-year follow-up survey to determine how treatment practices have developed in the ensuing decade. For continuity, the new survey was almost identical to the 2007 version, with minimal changes necessitated by a review of the literature to identify techniques that may have become commonplace since the initial survey. In the future, the survey data will be assessed to determine how demographic characteristics correlate with changes in treatment practices in the last decade. 


\section{Literature Review}

Several factors may have significantly influenced the resources and focus of conservation laboratories since the first survey in 2007. First, as research libraries increasingly acquire similar general collections resources as large digital collection subscriptions, special collections have become an ever more vital means for libraries to distinguish themselves and to support local teaching and research with unique specialized content. As Pritchard noted in 2009, "special collections have become even more important as a differentiating characteristic of research universities, the equivalent of unique laboratory facilities that attract faculty and research projects." ${ }^{3}$ Many research institutions have broadened their definition of "special collections" beyond rare books and manuscripts to include archival collections, international or area studies, and other topical or specialized collections that distinguish one library from another, often under the rubric of "distinctive collections." For example, the University of Texas at Austin defines their distinctive collections as "consisting of unique, rare and contextually significant collections of materials and providing abundant opportunities for scholarship. . . . These collections have particular value and meaning in that they represent specialized areas of research, are historically significant, have specific contextual value, or are rare or unique in terms of content and/or format." Similarly, Northwestern University's Distinctive Collections unit was created to comprise "all rare and unique materials, along with select subject collections of extraordinary depth" including focus in African Studies, art, special collections, music, transportation, and the University Archives. ${ }^{5}$

Over the last decade, many conservation units have added staff trained in treatment of special collections materials where staff additions to care for general collections have been relatively rare. According to the latest published American Library Association (ALA) Preservation Statistics Survey, preservation and conservation "expenditures on professional staffing [most typically associated with special collections treatment] rose 14 percent" over a period from 2008 to 2012. ${ }^{6}$ Miller and Horan, in a review of position announcements for preservation professionals from 2004 to 2015 , noted that "special collections conservation [is] more likely to remain present in job advertisements," versus a "de-emphasis on many aspects of treatment and care of circulating collections."

In many research libraries, the quantity of general collections book repair has declined in the last decade, as have many libraries' commercial binding budgets. ${ }^{8}$ In a comparison of the 2008 and 2012 Association of Research Libraries (ARL) survey results, Peterson et al. found that a decrease in the number of treated bound volumes and pamphlets was driven by a "reduction in the rate of level 1 treatments (those that require fewer than fifteen minutes of staff time per item), which appeared to decline by 86 percent from 2008 to 2013." Additionally, they correlated the reduction in level 1 treatments with a reduction in nonprofessional staffing most likely to perform level 1 treatments. ${ }^{10}$ These data indicate that the quantity of minor treatments more typical to general collections, along with the staff who perform them, appear to be declining. Miller and Horan found a similar reduction in positions advertising for circulating book repair treatment (41 to 11 percent), indicating that there have been fewer advertised positions focusing on the treatments that are more likely to be performed by technicians than professionals with graduate degrees. ${ }^{11}$

The growth of digitization initiatives in research libraries has placed new demands on conservation over the past decade, significantly affecting the treatment approaches employed by conservation professionals and impacting staffing needs. Gracy and Kahn stated in 2012 that "digitization is no longer an emerging tool; it is the established and often preferred method for reformatting." 12 In response to the changing context, conservation professionals have adapted their treatment practices. Treatments required to support digitization are typically not extensive but tend to consist of minimal stabilization prior to scanning. As noted by panelists in the 2008 Library Collections Conservation Discussion Group (LCCDG) at the American Institute for Conservation (AIC) annual meeting, there has been a "shift from ... treatments for handling and use in a reading room towards treatments concerned with the requirements of imaging systems." ${ }^{\text {"3 }}$ Furthermore, Boal noted that "structural reinforcements and stabilization treatments were utilized with less frequency in contrast to humidification and flattening of materials for imaging."

The formal education of research library conservators has also significantly shifted in the last decade. In 2009, the University of Texas at Austin conservation training program closed. As the only graduate-level training program specifically dedicated to training library and archives conservators in North America, its closure left a void for individuals hoping to gain professional credentials. As a result, the Andrew W. Mellon Foundation funded the development of book conservation training at the three American fine art conservation training programs: Buffalo State, the State University of New York; Winterthur/University of Delaware; and New York University. The first students from these programs specializing in library and archives materials graduated in $2013 .{ }^{15}$ It is likely too soon to determine whether they possess a markedly different repertoire of treatments from each other or from graduates of the Texas program.

In addition to formal education changes over the past decade, the AIC Wiki has greatly expanded as a clearinghouse for documented treatment practices, among other topics. ${ }^{16}$ Born as an electronic landing place for various types 
of conservators' Conservation Catalogs (including the Paper Conservation Catalog and the Book Conservation Catalog), the AIC Wiki has been updated and expanded to new areas. Volunteers from the conservation community collaboratively share information about treatment practices and materials, preventive care, education and training, work practices, and research and analysis. Given the exponential increase in the depth, breadth, and accessibility of this resource, it is likely that conservators are consulting it more frequently for treatment advice than in 2007.

\section{Surveys of Conservation Treatment Methods, 2007-2017}

In the last decade, a few publications reported on surveys of book conservation treatment practices. In 2011, Teper and Straw described an assessment of leather treatment practices. ${ }^{17}$ Their paper documented how frequently their fifty-seven respondents used standard treatments for leather books such as board reattachments, rebacking, hinge repair, and rebinding. They also gathered data on adhesives, consolidants, and materials used for repair. The survey respondents included book dealers, curators, and preservation administrators plus conservators. Also in 2011, Kearney explored the use of Japanese paper in leather repair, reporting on findings of an eight-question survey. ${ }^{18}$ The study documented repair techniques and materials, and asked respondents to comment on why certain techniques were preferred. In 2016, Alexopoulou and Zervos, who conducted an international survey of paper conservation methods, found that conservators prefer time-tested techniques for dry-cleaning, washing, and deacidification to newer methods. ${ }^{19}$

On a broader scale, Peterson et al. reported on the implementation of a new high-level preservation statistics program, following the termination of the Association of Research Libraries (ARL) preservation statistics. ${ }^{20}$ The National Preservation Statistics Survey did not gather details about specific preservation techniques, but rather captured extensive demographic information and an administrative view of current practices and staffing levels among research library preservation programs.
Table 1. Demographic characteristics and number of treatment cases, 2017

Respondents

Treatment Cases

\begin{tabular}{lcccc} 
Type & No. & Collections & Collections & Total \\
Hybrid practitioners & 57 & 57 & 57 & 114 \\
Special collections only & 51 & 51 & - & 51 \\
General collections only & 14 & - & 14 & 14 \\
Total & 122 & 108 & 71 & 179 \\
\hline
\end{tabular}

Table 2. Respondents' institutions, 2007 vs. 2017

\begin{tabular}{|c|c|c|c|c|c|}
\hline Question & Response & No. & $\%$ & No. & $\%$ \\
\hline \multirow[t]{4}{*}{ Size of institution } & Fewer than 2 million volumes & 24 & 33 & 17 & 14 \\
\hline & 2-3 million volumes & 28 & $38^{\mathrm{a}}$ & 10 & 8 \\
\hline & 3-5 million volumes & & & 26 & 21 \\
\hline & More than 5 million volumes & 21 & 29 & 69 & 57 \\
\hline \multirow[t]{2}{*}{ Type of research library } & ARL & 59 & 81 & 101 & 83 \\
\hline & Non-ARL & 14 & 19 & 21 & 17 \\
\hline \multirow[t]{5}{*}{ Type of conservation/repair facility } & Special collections only & 2 & 3 & 11 & 9 \\
\hline & General collections only & 7 & 10 & 2 & 2 \\
\hline & Centralized/hybrid facility & 48 & 66 & 77 & 63 \\
\hline & Separate facilities & 15 & 21 & 27 & 22 \\
\hline & Other & 1 & 1 & 5 & 4 \\
\hline \multirow[t]{6}{*}{ Year facility built or last renovated } & $2010 \mathrm{~s}$ & N/A & N/A & 32 & 30 \\
\hline & $2000 \mathrm{~s}$ & 32 & 44 & 44 & 40 \\
\hline & $1990 \mathrm{~s}$ & 16 & 22 & 21 & 19 \\
\hline & $1980 \mathrm{~s}$ & 10 & 14 & 12 & 11 \\
\hline & Pre-1980s & 10 & 14 & N/A & N/A \\
\hline & Other & 5 & 7 & N/A & N/A \\
\hline
\end{tabular}

a The 2007 survey had only three categories for institution size, with the middle category encompassing "2-5 million volumes."

\section{Survey Method}

\section{Survey Goals and Scope}

To ensure consistency and determine whether changes to the survey instrument were warranted, both the 2007 survey data and literature from the past decade were reviewed. Treatments that were deemed extremely low-use in 2007 would not be included in the 2017 survey if there were no new publications or references to them in the ensuing decade. These changes were not made lightly to maintain continuity for comparison with the 2007 data. Nevertheless, three treatments fit the description: (1) leather-covered box, which 4 percent of special collections and 2 percent of general collections practitioners reported as standard practice in 
2007; (2) paperback stiffening, which 4 percent of special collections and 12 percent of general collections practitioners had reported as standard practice; and (3) in-house use of Wei T'o deacidification spray, which 9 percent of special collections and 5 percent of general collections practitioners had reported as standard practice. Moreover, the literature was examined to identify any new book treatment techniques for both general and special collections introduced in published form, through workshops, or via social media in the last decade. Included in the search were proceedings of professional meetings such as AIC's Book and Paper Group Annual, the AIC Wiki, and less formal social media outlets such as blogs of individual conservators.

While most of the techniques identified in this search were more relevant to book arts, a few new conservation techniques associated with

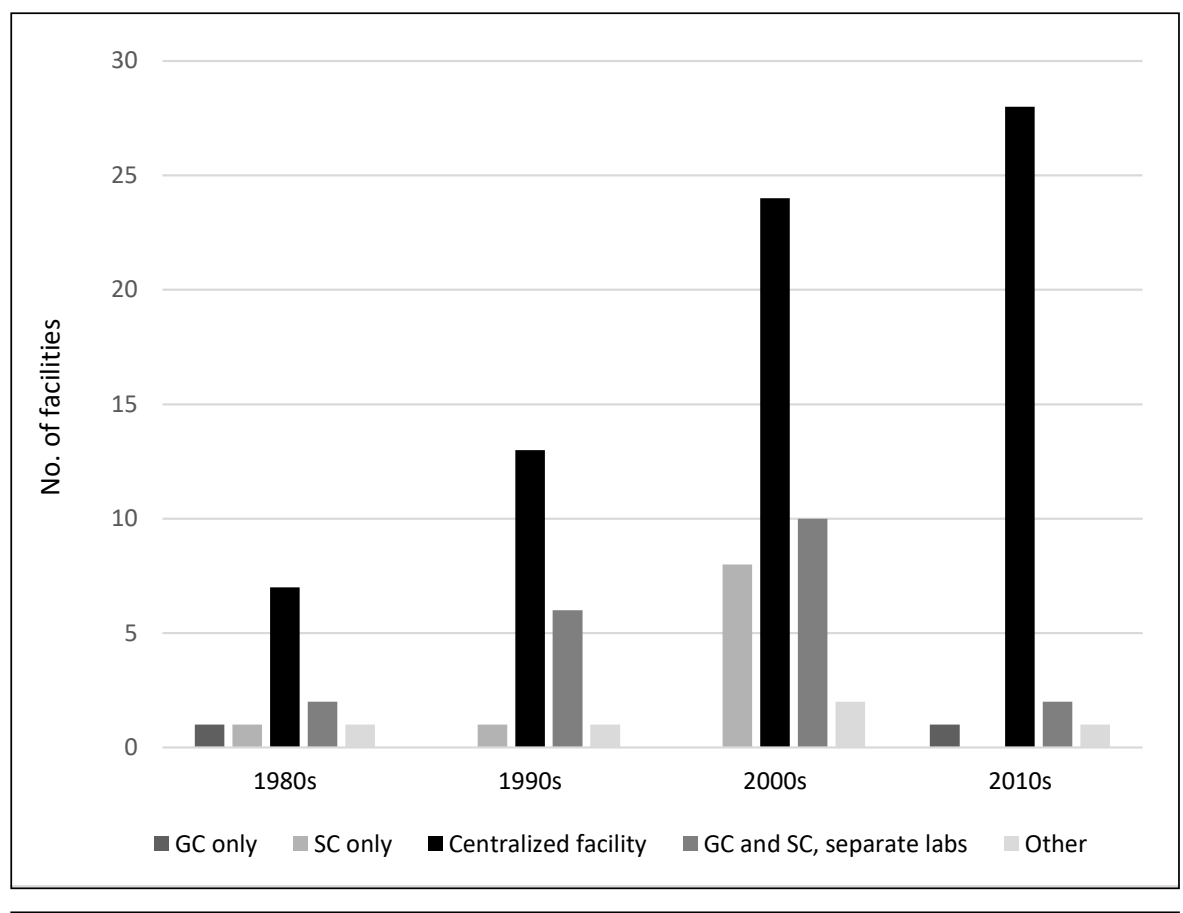

Figure 1. Facility type vs. decade renovated minor paper treatment and textblock repair had received widespread publicity: the use of remoistenable and solventset tissues in mending paper and toning Japanese paper for mends or fills. Remoistenable and solvent-set mending tissues were the topic of many publications since 2007 and a series of hands-on workshops hosted by the American Institute for Conservation and the Guild of Book Workers. ${ }^{21}$ The toning of Japanese paper was perceived as a common practice in many labs that was inadvertently omitted from the 2007 survey.

The overarching research questions for the 2017 survey include four questions that are identical to those posited in 2007, plus one addition:

- What constitutes the "standard toolbox" of book conservation treatments for general and special collections near the beginning of the twenty-first century?

- Are the same types of treatments employed for general collections as special collections?

- Which treatments are applied similarly in both contexts?

- Which are more common in one context or the other?

- New: Have treatment practices changed in the last ten years? If so, how?

\section{Survey Design}

To compare practices over time, the survey structure developed ten years ago was reused. Advances in survey technology in the ensuing decade facilitated improvements in data analysis and lowered operator error. The new technology targeted survey candidates with personalized invitations and follow up messages, which may have increased participation. Qualtrics software was selected for the 2017 survey.

The survey instrument consisted of four sections: audience definition and participation disclaimer, demographic questionnaire, treatment questionnaire(s), and a request for voluntary follow-up (appendix A). To ensure the survey's relevance to both general and special collections practitioners and to permit a comparison of practices, the questionnaires pertaining to general and to special collections treatment practices were identical, containing fifty-four treatments in seven categories that could be applied to bound materials in either a general or special collections setting: (1) protective enclosures, (2) binding reinforcements, (3) minor paper treatments and textblock repairs, (4) board reattachment methods, (5) rebinding styles, (6) binding repair techniques, and (7) advanced paper treatments performed on bound materials. ${ }^{22}$ Where treatment names were not sufficiently self-explanatory, definitions were supplied with the treatment (see appendix B).

The survey design enabled respondents to provide treatment information-as appropriate to their responsibilities-for only general collections treatment, only special collections treatment, or both. Individuals with responsibility for one type of collection-general collections or special collections - were asked to complete one page of identical treatment questions, while respondents with responsibility 


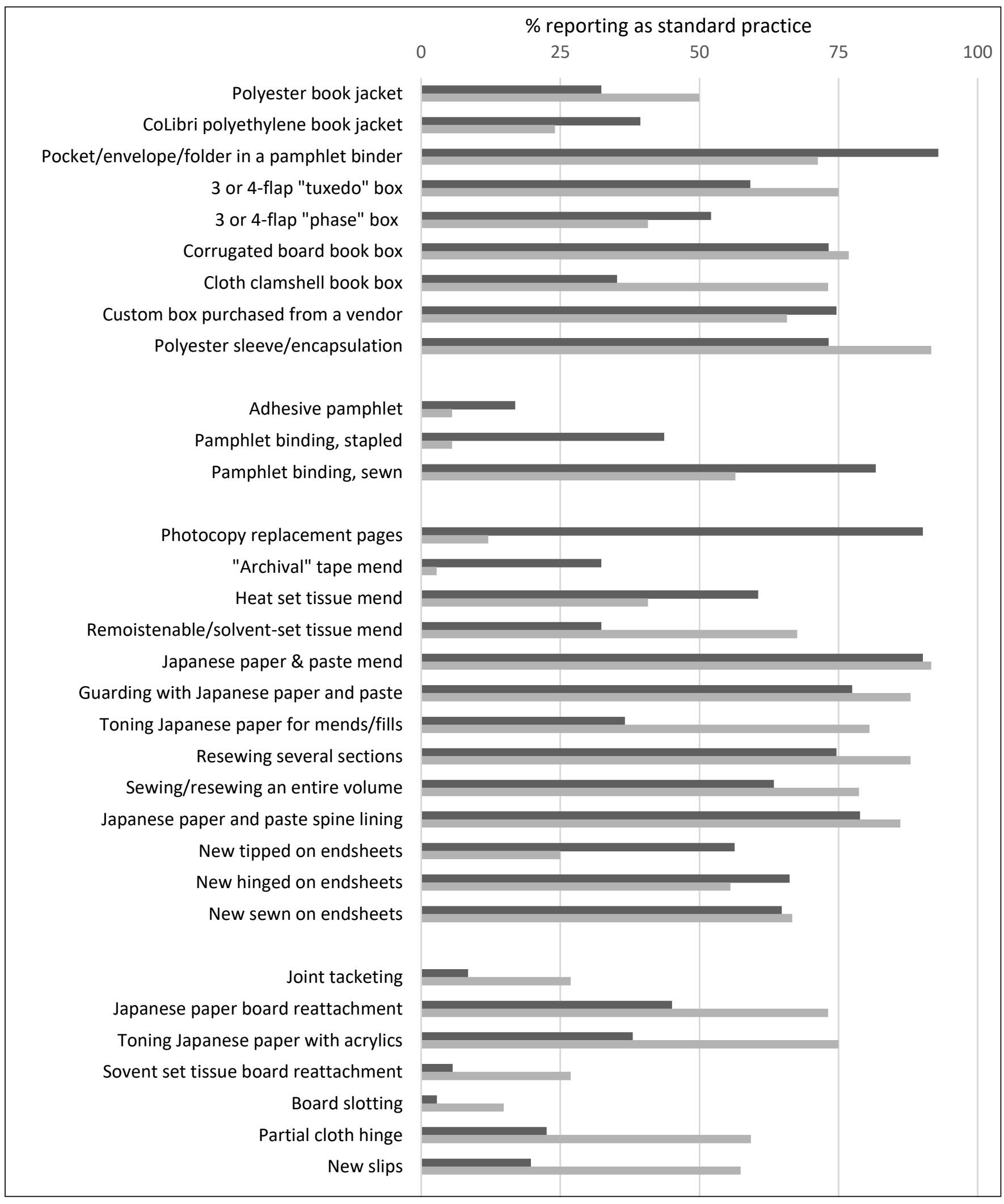

Figure 2 (part 1). Treatment practices employed for general and special collections, 2017 


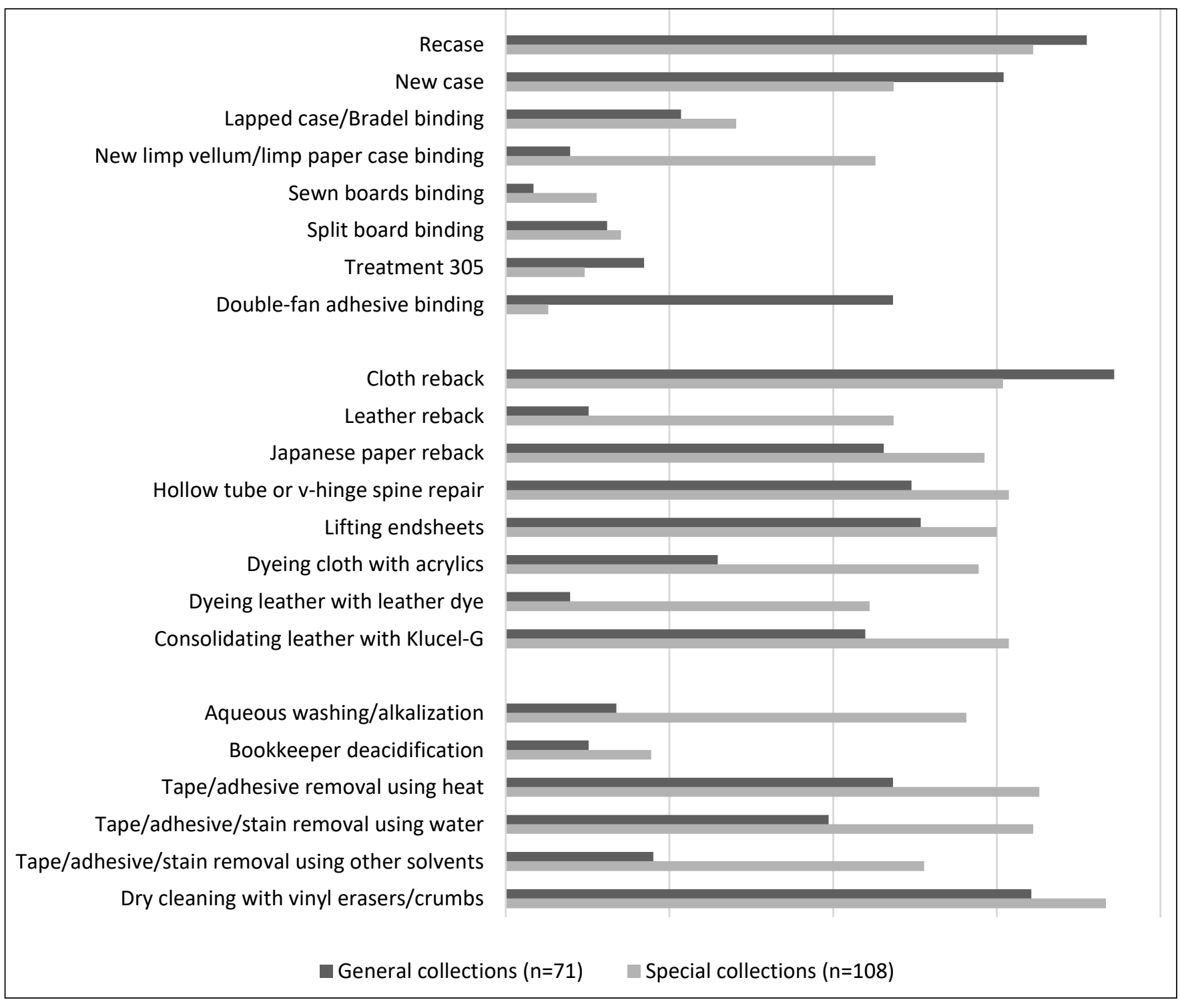

Figure 2 (part 2). Treatment practices employed for general and special collections, 2017

for both general collections and special collections received two pages of questions, one for each type.

As in 2007 , the survey prompted respondents to identify how routinely during the past three years they used each treatment by selecting from a set of response options. When the response options were developed in 2007, the authors avoided references to quantitative terms such as "weekly" or "monthly"; overly vague entries like "frequently" or "rarely"; and to specific production output levels that might favor larger repair operations over smaller. The 2017 survey retained the five treatment response options employed in 2007: (1) standard practice, frequent; (2) standard practice, occasional; (3) anomalous use only; (4) never; and (5) not sure. Following each category of treatment, respondents were invited to list other treatments in a free-text field.

Because the original survey underwent rigorous pretesting to refine the treatments, treatment definitions, and treatment frequency response options, pretesting for the 2017 survey focused primarily on operability of the survey platform, although other feedback was welcomed. Seven pretesters-representing individuals trained in various graduate programs or by apprenticeship and at various points in their careers-reviewed the 2017 survey.

\section{Survey Implementation}

The 2007 survey was evaluated and updated to ensure a more robust and representative response in the 2017 
version. Improvements in survey technology aided in this process. In 2007, the survey was distributed through various professional discussion lists via a common web link. Respondents were invited to answer once for each treatment facility and international participation was encouraged. Although the survey was anonymous, 81 percent of respondents voluntarily identified themselves, affording insight into the response pool. Most respondents were from ARL or Independent Research Libraries Association (IRLA) institutions. Additionally, only six respondents were from outside the US. Before analysis, international data was omitted because it was insufficient to support generalizations about international practices or comparisons to US practices. ${ }^{23}$ To facilitate comparison to the 2007 data, the 2017 survey was limited to respondents from ARL and IRLA libraries in the US.

As survey technology improved, and because there was no way to ensure that only one person per lab answered the survey in 2007, multiple responses per institution were included to more accurately capture standard practices across the field. In many smaller institutions, there would still be one respondent as in 2007 , but for larger institutions, multiple respondents could participate, enabling a clearer picture of how research library collections are treated overall. Furthermore, since large institutions often employ conservation professionals with diverse training experiences, greater participation could invite wider perspectives.

The 2017 survey respondents were gathered from ARL and IRLA libraries in the US. A list of conservation practitioners at these institutions was compiled via a search of institutional websites and the AIC member directory. Personalized email invitations were distributed via the Qualtrics survey tool. The survey asked respondents to suggest colleagues at their institution who might not have received a survey invitation or who might be better suited to respond to the survey. While most of the individuals suggested through this process had already been invited to participate, a few new individuals were identified and sent the survey link. The initial survey invitations were sent to 198 individuals. An additional fourteen were suggested by respondents, for a total of 212 individuals invited during the survey period.

When the survey went live, two annual

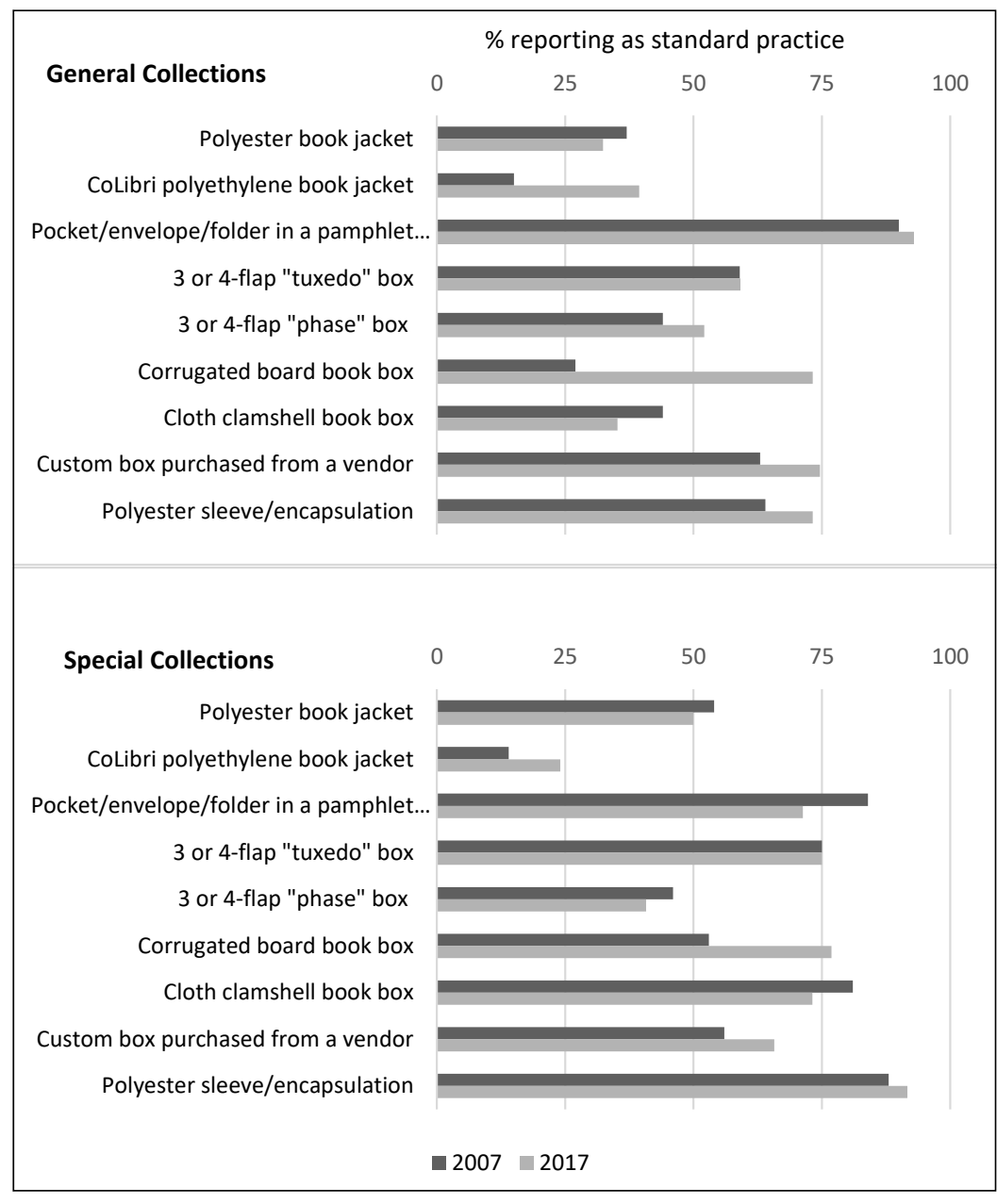

Figure 3. Protective enclosures, 2007 vs. 2017

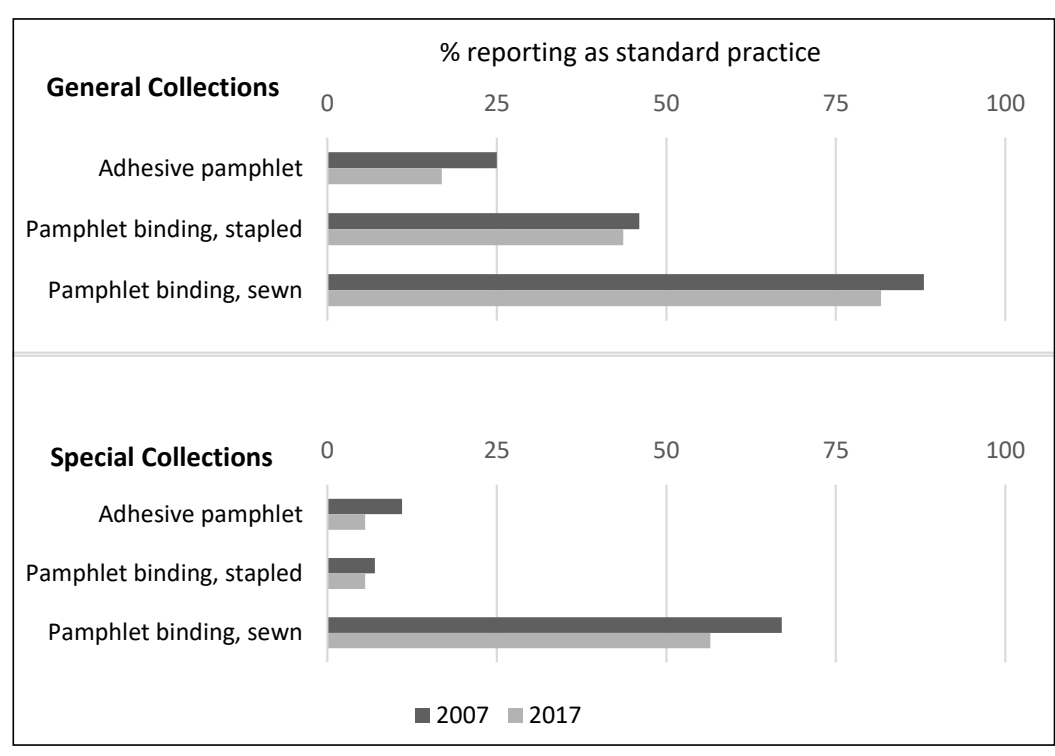

Figure 4. Binding reinforcements, 2007 vs. 2017 


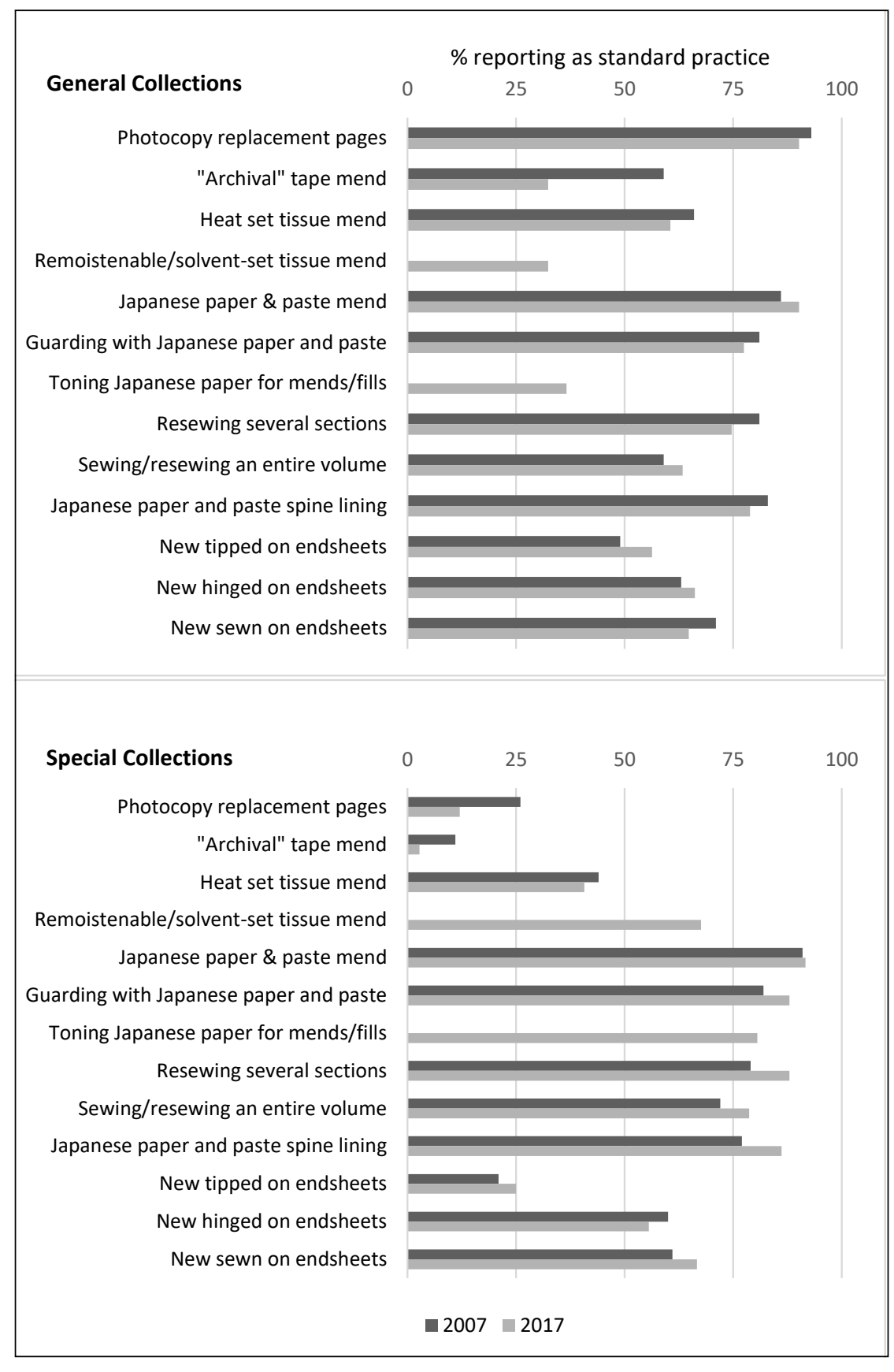

Figure 5. Minor paper treatments and textblock repairs, 2007 vs. 2017 the Preservation Administrators Group at the ALA Annual Conference. The survey period ran from June 22 to July $21,2017$. All respondents who had not completed the survey after two weeks and those who had started but not finished it were sent a reminder email with the same personalized link based on email addresses, generating a wave of additional responses in early July.

\section{Survey Limitations}

Although the survey results have a high degree of confidence, some potential sources of error are associated with the survey process. Despite attempts to locate everyone qualified to participate in the survey, it is possible that not all preservation professionals employed by all ARL and IRLA libraries were contacted. It was difficult to confirm that all individuals had been reached with 100 percent confidence, especially at institutions without a preservation department. Contact information on library websites may have been incomplete or outdated. At those institutions, book repair may be located in technical services, collection development, or some other area, and despite extensive searching, one could not be completely confident that repair activities did not take place at those institutions because of limited or no web presence.

Institutional websites vary greatly in quality; in some instances, employee directories were not conducive to searching for job titles, and some preservation employees had non-descriptive, generic titles such as "library assistant," making it difficult to determine job function from a directory listing. In a few cases, libraries did not have a publicly searchable list of employees, so professional membership directories were consulted even though meetings attended by many conservation and preservation professionals also took place. To promote the survey, informational cards about the research were distributed among potential respondents at the 2017 AIC Annual Meeting in Chicago. Although not all the targeted survey audience attended the meeting, this effort may have increased the survey sample size. Additionally, while the survey was live, it was announced during an open informational session at not every conservation professional is a member of a professional organization.

Additionally, some individuals may not have received the survey announcement because of email spam filtering, others might have felt unqualified to participate, and others might have experienced unreported technical difficulties with the survey that may have resulted in failed response attempts. Some individuals indicated that they took the 


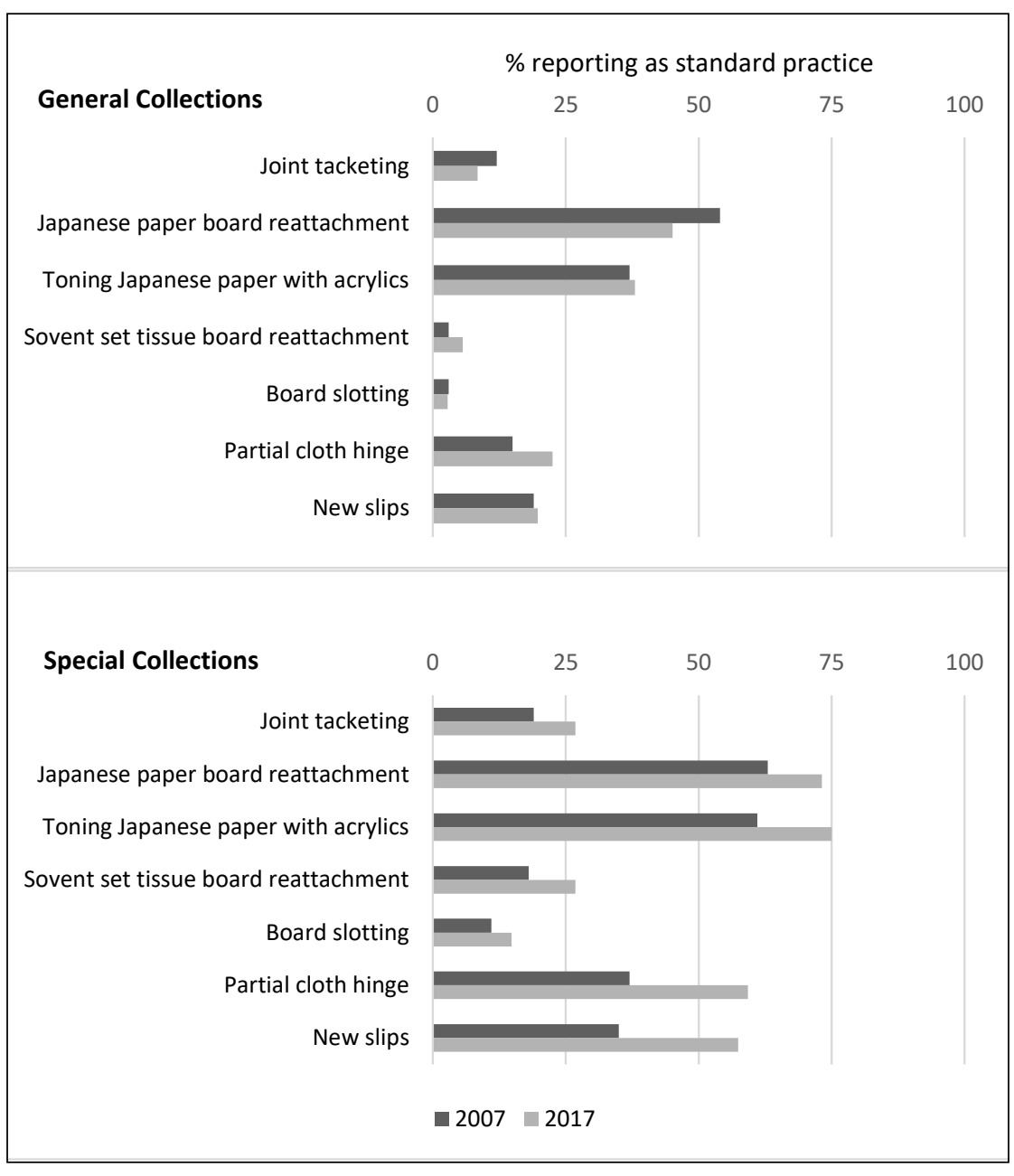

Figure 6. Board reattachment methods, 2007 vs. 2017

survey on behalf of everyone in a department or conservation laboratory rather than allowing all practitioners to take the survey for themselves. When individuals replying for the entire lab indicated as much in the survey comments, they were encouraged to allow each person to respond individually, but that did not always happen. Although fact based, the survey was based on people's perceptions of what constitutes "standard practice"; some respondents may have reported inflated or deflated practices based on aspirations or humility rather than actual practice.

There are some sources of error associated with the survey instrument itself. Not all treatments may have been recognizable to survey respondents even when descriptions were included with treatment names in the survey. Despite extensive research, some common treatments may have been missed. Finally, while the 2017 survey software provided analytical tools that have greatly decreased human error in analysis, some human error was still possible in interpreting results.

\section{Survey Results Demographic Characteristics}

Of the 212 invited, 122 respondents from US research libraries fully completed the survey, resulting in a 58 percent response rate. When compared with seventy-three respondents in 2007 , this total represents a 40 percent increase. Because the respondent population size has been calculated, the 2017 survey response rate has a much greater degree of confidence than for the 2007 survey, in which the respondents answered anonymously and the population size was unknown. Ninety-eight percent of respondents provided contact information, indicating willingness to respond to follow up questions if necessary.

The survey sample was relatively diverse with respect to collected demographic characteristics; respondents were almost evenly matched between those holding positions with hybrid responsibilities involving both special and general collections (47 percent) and those working only with special collections (42 percent). Only 11 percent of respondents worked solely with general collections. The 122 respondents provided a total of 179 treatment cases because the fifty-seven hybrid respondents were asked to complete two treatment questionnaires, one for each type of collection, while the remaining 65 respondents completed one questionnaire each (see table 1).

More than half of respondents worked for institutions with over five million volumes, a significant increase over the 2007 survey results (57 percent, compared with 29 percent in 2007). This may be partly attributed to allowing multiple responses per institution rather than one summary response, as large institutions typically employ many conservators. The number of respondents from mid-size libraries remained relatively constant, while the number of respondents from institutions with fewer than two million volumes declined. With respect to their conservation facilities, twothirds of respondents (63 percent) work in a centralized or hybrid facility and almost a third (30 percent) work in a facility that was built or renovated since 2010 (see table 2).

The 2017 data for facility type and decade of construction or renovation were correlated to determine which types of facilities have been most common over time. The data confirm the continuation of a trend observed in the first study: the vast majority of new or renovated laboratories are 
hybrid facilities serving both general and special collections (see figure 1).

\section{Treatment Practices}

The collected data pertaining to treatment practices were compiled and graphed, comparing general collections and special collections practices. Each treatment was classified-once for general collections and again for special collections - as either "standard practice," "moderate use," or "low use." A treatment was designated "standard practice" when it was reported as "standard practice, frequent" or "standard practice, occasional" by 50 percent or more of the respondents. Treatments reported as standard practice by 25 to 49 percent of conservation units were designated "moderate use," while the remaining treatments-those considered standard practice by fewer than 25 percent of units - were designated "low use."

Further discussion of the data follows, organized by category of treatment with both a comparison of general and special collections practices in 2017 and a comparison of how general and special collections treatments have changed since 2007 within those respective categories. Figure 2 shows the overall 2017 data for both general and special collections; graphs comparing responses from 2007 and 2017 are provided individually.

\section{Protective Enclosures}

The data indicate that protective enclosures are regularly employed in the treatment of both general and special collections; in 2017, six of the eight enclosures qualified as standard practice for general collections and seven for special collections. Only one qualified as low use and only for special collections: Colibri book jackets. Difference in practice between general and special collections was most pronounced for the cloth clamshell box, which is significantly more common to special collections, a difference of $[\Delta] 38$ percentage points. ${ }^{24}$

In 2017, four types of protective enclosures were more common to general than special collections: Colibri book jacket $(\Delta 15)$, pocket/envelope/3 or 4 -flap folder in a pamphlet binder $(\Delta 22), 3$ - or 4 -flap "phase" box $(\Delta 11)$, and custom boxes purchased from a vendor $(\Delta 9)$. The five treatments more common to special collections were polyester book jacket $(\Delta 18), 3$ or 4-flap "tuxedo" box $(\Delta 16)$, corrugated clamshell book box made in-house $(\Delta 4)$, cloth clamshell box $(\Delta 38)$, and polyester sleeve encapsulation $(\Delta$ 19) (see figure 2 ).

A comparison of the data from 2007 to 2017 shows a marked move toward more utilitarian, mass-produced, and less expensive enclosures in both general and special collections contexts. Corrugated book boxes constructed in-house, ordering custom boxes from a vendor, and Colibri dust jackets are much more commonly employed in 2017 than in 2007 (see figure 3).

\section{Binding Reinforcements}

As reported in 2007 , this category still includes many of the least commonly employed treatments; changes since 2007 for use in both general and special collections were 
quite small in this category. Only one type of binding reinforcement was reported as standard practice in 2017 for both general and special collections: sewn pamphlet binding. This treatment is much more commonly employed in a general collections context $(\Delta 26)$, although it is a common practice for both types of collections. Adhesive pamphlet binding was reported as very low use for both general and special collections, and stapled bindings were moderate use for general collections but low-use for special collections (see figure 2). All treatments in this category continue to be more frequently used in the general collections context. All treatments in this category decreased slightly in 2017 for both general and special collections (see figure 4).

\section{Minor Paper Treatments and Textblock Repairs}

This category of thirteen treatments includes ten that were reported in 2017 as standard practice for general collections and nine for special collections. This category includes the treatment with the greatest disparity in use between general and special collections: photocopied replacement pages, with a $\Delta$ of 78 percentage points. The majority of the treatments in this category are highly employed in both contexts, however "archival" tape mending

$(\Delta 29)$, heat-set tissue mending $(\Delta 20)$, and new tipped-on endsheets $(\Delta 31)$ are much more common in the general collections context. Conversely, toning Japanese paper for mends or fills $(\Delta 44)$ and using remoistenable tissue mending $(\Delta 36)$ are much more common in the special collections context (see figure 2). The other treatments in this category were quite similarly employed in both contexts in 2007 and continue to be in 2017. The new additions to the survey (remoistenable tissue mending and toning Japanese paper) were much more commonly used in the special collections context (see figure 5).

\section{Board Reattachment Methods}

This category includes treatments not commonly employed in general collections-none was considered standard practice in 2017. Four were considered standard practice for special collections: Japanese paper board reattachment, toning Japanese paper with acrylics, partial cloth hinge, and new slips; two were moderate use: joint tacketing and solvent-set tissue board reattachment. Only board slotting was low use in the special collections context. In contrast, most of these treatments were low-use for general collections, with only Japanese paper board reattachment and toning Japanese paper with acrylics rising to the "moderate use" category (see figure 2 ).

When compared with the 2007 data, Japanese paper board reattachment has fallen from a standard practice in the general collections context to a "moderate use" treatment. As found in 2007, all of these treatments are more commonly employed in the special collections context, and all treatments in the special collections category rose in frequency of use since 2007 (see figure 6).

\section{Rebinding Styles}

For the 2017 data, recase and new case are considered standard practice for both general and special collections. 


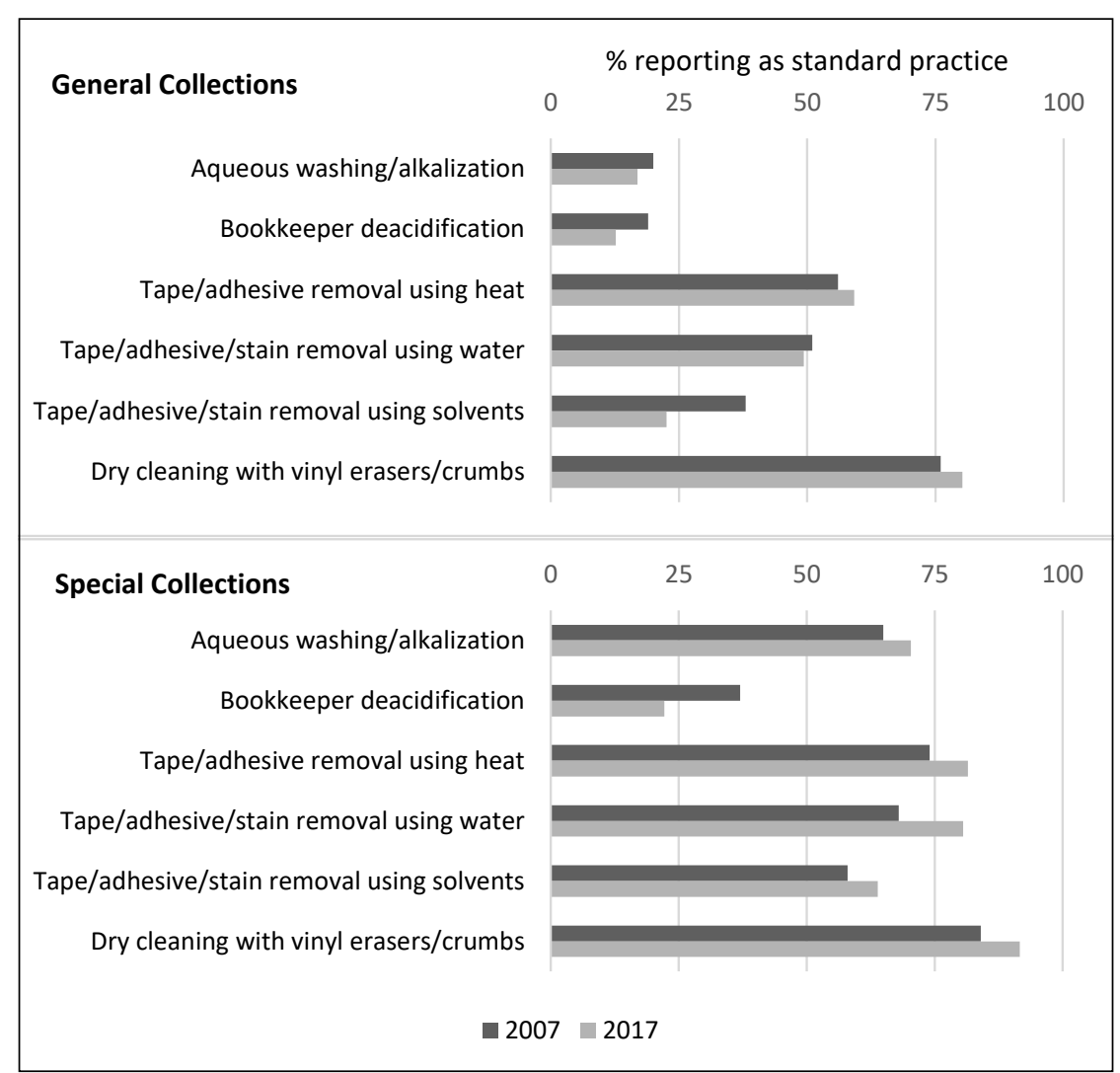

Figure 9. Advanced paper treatments, 2007 vs. 2017

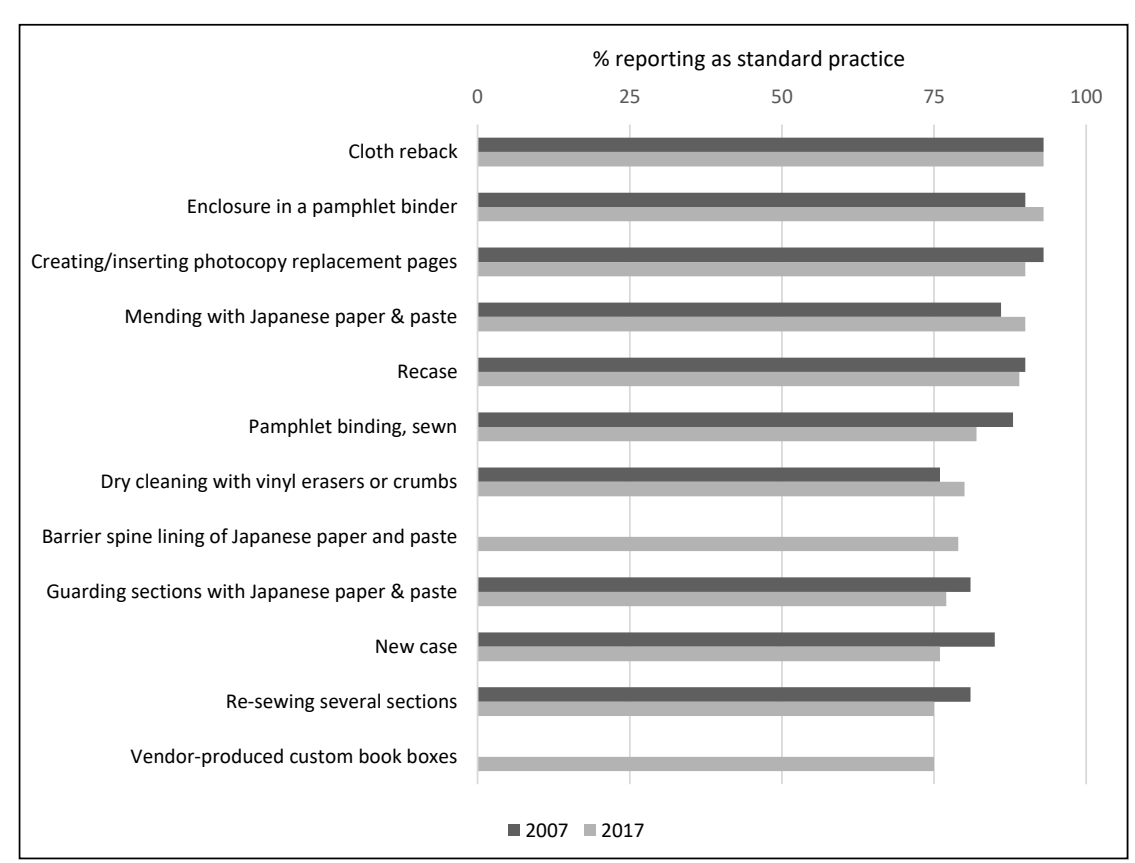

Figure 10. General collections treatments reported as standard practice by $\geq 75 \%$ of respondents, 2007 vs. 2017
Furthermore, new limp vellum/paper case is standard for special collections materials and double-fan adhesive binding for general collections-both of these treatments increased in frequency since 2007. Three of the rebinding styles were more common to general collections: recase, new case, and double-fan adhesive binding. The treatment with the greatest difference in practice is double fan adhesive binding, with $\Delta 53$ percentage points in favor of general collections. A close second is new limp vellum/limp paper case binding, with a $\Delta 47$ percentage points in favor of special collections. The other treatments were employed at quite similar rates between general and special collections, with differences of 17 percentage points and below. Sewn boards binding, Treatment 305, and split board binding are low use in both contexts (see figure 2).

When compared with the 2007 findings, recase and new case continue to be standard practice in both contexts. There was a marked increase in the use of vellum/paper case bindings in the special collections context and a marked increase in the use of Treatment 305 for general collections, although it is still in the lowuse category (see figure 7).

\section{Binding Repair Techniques}

All the treatments in this category were considered standard practice in the special collections context and five of the eight were standard practice for general collections. All but one treatment in this category were much more common in the special collections context, the exception being cloth reback. The most significant gap between general and special collections was for two treatments with $\Delta 46$ percentage points: leather reback and dyeing leather with leather dye. Dyeing cloth with acrylics had a $\Delta 40$, also in favor of special collections (see figure 2).

All general and special collections treatments remained the same or increased in application frequency since 2007 with the exception of consolidating leather with Klucel-G. For general collections, the greatest increases appeared for Japanese 
paper reback and using a hollow tube or v-hinge for spine repair. For special collections, quite a few treatments showed significant increases, including leather and Japanese paper rebacks, dyeing cloth with acrylics and leather dye, hollow tube or v-hinge spine repair, and lifting original endsheets (see figure 8).

\section{Advanced Paper Treatments Performed on Bound Materials}

In 2017, all but one of the treatments in this category were standard practice for special collections; the exception was the use of Bookkeeper deacidification spray, which was low-use for both general and special collections. In the general collections context, there was a mixture of standard practice, moderate use, and low-use treatments. Dry cleaning with vinyl erasers or crumbs was very commonly employed in both types of collections, as was true in 2007 (see figure 2).

When compared with the 2007 data, all treatments in this category continue to be more common to special collections than to general collections: aqueous washing and deacidification had a $\Delta 38$ in 2007 in favor of special collections. The gap has now widened considerably, to $\Delta$ 53 between general and special collections use. The use of Bookkeeper spray is less common in both contexts than in 2007. Only two treatments increased in frequency of use in the general collections context: tape removal with heat and dry cleaning with vinyl erasers or crumbs. Overall, changes in this category were subtle (see figure 9 ).

\section{Highly Standard Practice Treatments}

Treatments reported as "standard practice" by 75 percent or more of respondents were classified as "highly standard practice," comparing what was identified in 2007 with what was added in 2017. For general collections, there was surprisingly little change: all ten highly standard practice treatments from 2007 remain on the list. There were only two additions: using a barrier lining of Japanese paper and paste in rebinding treatments (79 percent) and custom book boxes purchased from a vendor (75 percent) (see figure 10). The data indicate that general collections treatments are well codified, perhaps because of decades' worth of published book repair manuals and book repair workshops. Conversely, the research indicates that not much innovation in treatment practice has occurred in general collections practice in the past ten years.

For special collections, eight of the ten highly standard practice treatments from 2007 remain on the list, with two falling off, both in the category of protective enclosures: pocket or envelope in a pamphlet binder and cloth clamshell box. Ten additional treatments were added to the highly standard practice list for special collections: tape/adhesive/ stain removal using heat; tape/adhesive/stain removal using water; toning Japanese paper for mends or fills; recase; (re)sewing an entire volume; corrugated board book box; reattaching detached spines with a hollow tube or v-hinge; cloth reback; toning Japanese paper with acrylics for board reattachments; and lifting endsheets to save original pastedowns (see figure 11). The many additions to the special collections list may reflect an increased or increasing focus on special collections materials in the context of the rise of distinctive collections, may be a feature of conservation training being more focused on high-end treatments, or may reflect an increased respondent pool for special collections treatments. Should the survey be replicated in 2027, it will be interesting to note if the highly standard practices for 


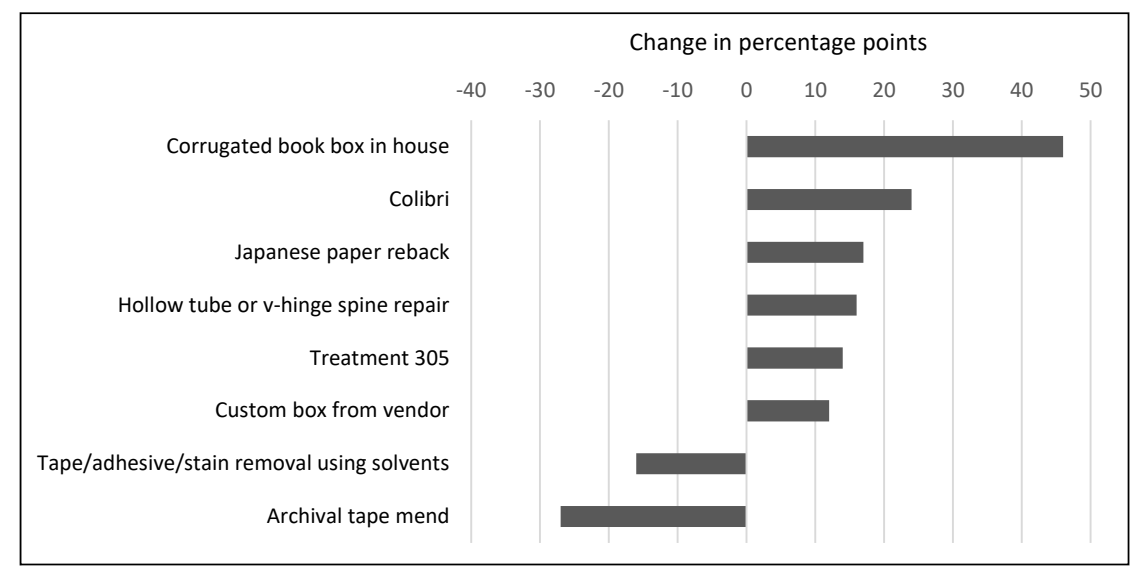

Figure 12. General collections treatments moving ten or more percentage points, 2007 to 2017

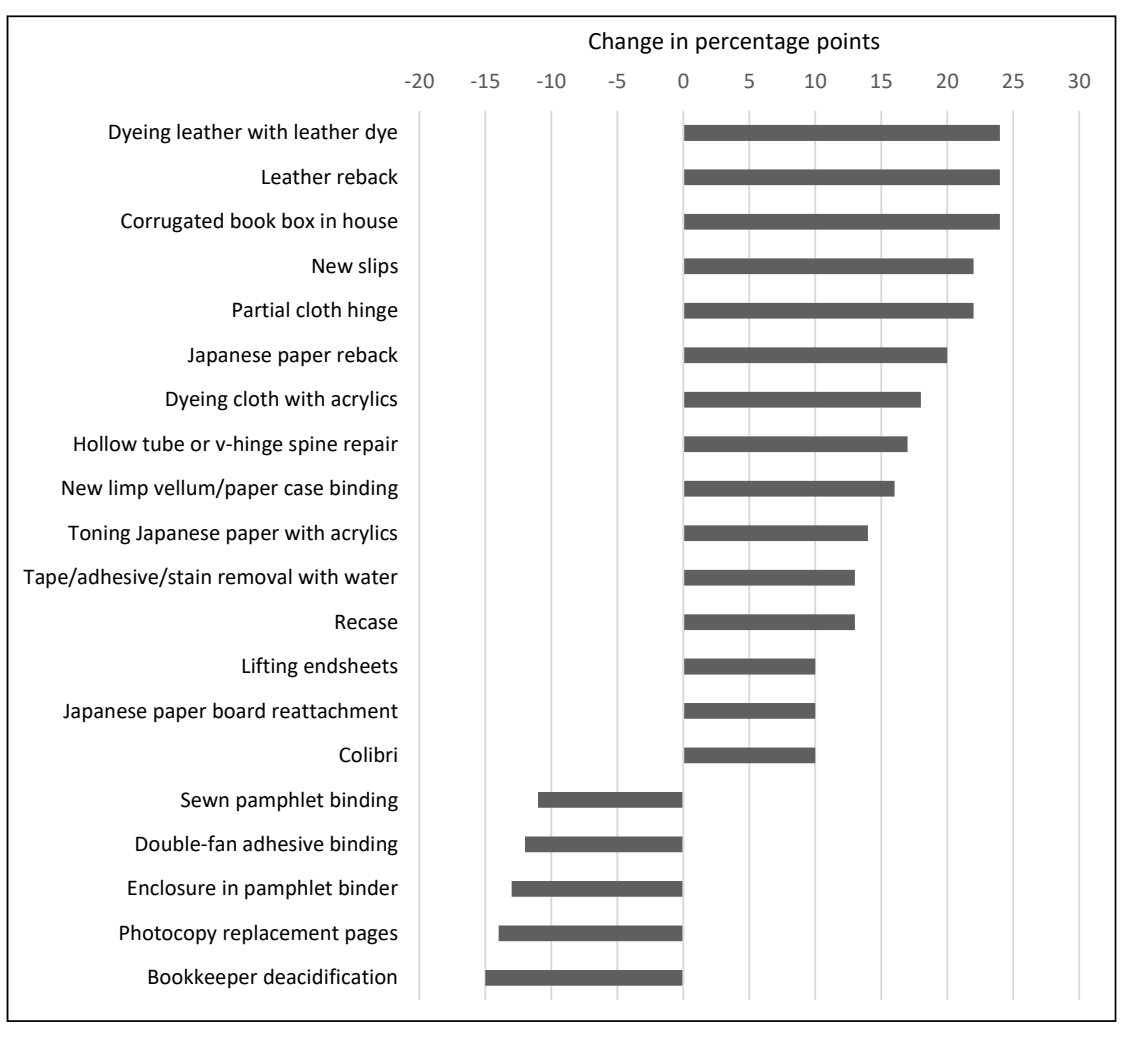

Figure 13. Special collections treatment moving ten or more percentage points, 2007 to 2017

special collections have become more codified, similar to what has been observed in the general collections context.

\section{Treatments with Significantly Different Adoption Levels in 2017 Versus 2007}

The 2007 and 2017 data were also analyzed for significant differences in "use frequency." A shift of ten or more percentage points was considered significant. Generally, for both general and special collections, many more treatments increased in popularity than decreased. In some cases, the difference was significant enough that treatments shifted into a new category, while for others, given that the categories were segregated in twenty-five-point increments, the treatments shifted but stayed in the same designations of "low use," "moderate use," or "standard practice."

By these criteria, in the general collections context, six treatments were employed significantly more in 2017 than in 2007 . In the category of protective enclosures, the in-house construction of corrugated book boxes $(\Delta+46)$, the use of Colibri dustjacket protectors $(\Delta+24)$, and using vendors to make custom enclosures $(\Delta+12)$ increased noticeably. Two repair techniques are used more frequently in 2017: Japanese paper reback $(\Delta+17)$ and hollow tube or $\mathrm{V}$-hinge spine repair $(\Delta+16)$. One relatively low-use rebinding technique, Treatment 305 , significantly increased in popularity $(\Delta+14)$. Only two treatments showed significantly reduced adoption levels in the general collections context in 2017 versus 2007: stain removal using solvents $(\Delta-16)$, and "archival" tape mending ( $\Delta$-27) (see figure 12). No general collections treatments decreased in frequency while staying in the same category.

In the special collections context, fifteen treatments showed significantly increased adoption levels. Five treatments newly qualified as standard practice: toning leather with dye $(\Delta+24)$, leather reback $(\Delta+24)$, new slips $(\Delta+22)$, partial cloth hinge $(\Delta+22)$, and new limp paper/vellum case binding $(\Delta+16)$. These treatments all require high-end skills for successful completion, perhaps supporting the view that special collections treatments have become more refined. Additionally, ten treatments that were standard practice in 2007 showed significantly increased adoption rates. Of the protective enclosures studied, the in-house construction of corrugated book boxes $(\Delta+24)$ and Colibri dustjackets $(\Delta+10)$ increased significantly, perhaps because they are less time-consuming and more economical to execute and do not use any damaging 
adhesives. Taking the time to tone repair material—dyeing cloth with acrylics $(\Delta+18)$ and toning Japanese paper with acrylics $(\Delta+14)$ —also saw significantly increased adoption rates. The already-popular use of Japanese paper as a repair material also increased significantly, both when used to perform rebacks $(\Delta+20)$ and as board reattachments $(\Delta+10)$. Additional increases were found with spine repair incorporating a hollow tube or v-hinge $(\Delta+17)$; recasing $(\Delta+13)$; the use of water as a solvent for tape, adhesive, and stain removal $(\Delta+13)$; and lifting original endsheets to preserve them during binding repair $(\Delta+10)$ (see figure 13).

In the special collections context, two treatments involving pamphlet structures that qualified as standard practice in 2007 saw significant decrease in popularity in 2017: sewn pamphlet binding $(\Delta-11)$ and a pocket, envelope, or flapped enclosure in a pamphlet binder $(\Delta-13)$. Two treatments identified in 2007 as low-use in special collections continued their decline: inserting photocopied pages to replace missing text $(\Delta-14)$ and the use of double-fan adhesive binding $(\Delta$ -12). Likewise, the use of Bookkeeper deacidification spray declined from moderate to low use $(\Delta-15)$.

\section{Conclusion}

This paper compares the findings of a 2007 survey and the current 2017 survey to establish and further refine a "standard toolbox" of treatments for general and special collections in the early twenty-first century. This study is unique in that it provides a quantitative synopsis of book conservation techniques employed in 2017 versus those of a decade prior-providing insight into the trajectory of conservation treatment approaches in research libraries. As noted in a publication about the 2007 survey, the study's designation of "standard practice," "moderate use," and "low use" treatments "can inform practitioners, administrators, conservation professionals, and those in related fields by facilitating peer-to-peer benchmarking of current practices." ${ }^{\text {25 }}$ By providing insight into the field's adaptation of newer and more effective treatments, the data also suggest areas for further professional development.

The treatment practices detailed here may continue to help codify practice through the specification of a core group of book conservation treatment techniques employed by many research libraries. The data help to clarify and reconcile actual practices versus theoretical best practices for book conservation and repair. The survey data indicate that treatments widely adopted as standard practice in the general collections context have changed relatively little in the last decade, affirming the existence of a defined "standard toolbox" of treatment techniques. In the special collections context, however, the survey data indicate that practices continue to evolve. The ten treatments newly qualifying as "highly standard practice" for special collections may point to significant shifts in practice in the field. These changes may result from a greater response rate from the 2017 practitioners or an increase in special collections conservator positions.

A second study will be conducted with the 2017 data to correlate survey responses to a variety of demographic factors such as type of practitioner, practitioner training, library size, and type of conservation facility and to compare the data with that collected in 2007. The survey may be replicated in 2027 to continue to track longitudinally the changes in conservation treatment, and to further explore these changes and how they relate to the rapidly evolving context of research libraries.

\section{References and Notes}

1. Whitney Baker and Liz Dube, "Identifying Standard Practices in Research Library Book Conservation," Library Resources \& Technical Services 54, no. 1 (2010): 21-39.

2. Liz Dube and Whitney Baker, "The Impact of Training and Institutional Context on Book Conservation Practices," Book \& Paper Group Annual 29 (2011): 143-60.

3. Sarah F. Pritchard, "Special Collections Surge to the Fore," portal: Libraries of the Academy 9, no. 2 (2009): 179.

4. University of Texas Libraries, "About the Collections: Distinctive Collections" (Austin: University of Texas at Austin Libraries), accessed December 21, 2017, http://legacy.lib. utexas.edu/about/distinct.

5. Northwestern University Libraries, "Position Announcement: Director of Distinctive Collections" (Chicago: American Library Association, Rare Books and Manuscript Section, 2015), accessed December 14, 2017, https://rbms.info/blog /news-events/position-announcement-director-of-distinctive collections/.

6. Annie Peterson, Holly Robertson, and Nick Szydlowski, "Do You Count? The Revitalization of a National Preservation Statistics Survey," Library Resources \& Technical Services 60, no. 1 (2016): 47.

7. Mary M. Miller and Martha Horan, "Evolving Roles of Preservation Professionals: Trends in Position Announcements from 2004 to 2015," Library Resources \& Technical Services 61, no. 4 (2017): 195-96.

8. Annie Peterson, Holly Robertson, and Nick Szydlowski, "Preservation Statistics Survey Report, FY2015" (Chicago: Preservation and Reformatting Section, Association of Library Collections and Technical Services, American Library Association, 2016): 8.

9. Peterson, Robertson, and Szydlowski, "Do You Count?" 47. 
10. Peterson, Robertson, and Szydlowski, "Do You Count?," 47.

11. Miller and Horan, "Evolving Roles," 190.

12. Karen F. Gracy and Miriam B. Kahn, "Preservation in the Digital Age," Library Resources \& Technical Services 56, no. 1 (2012): 25.

13. Sarah Reidell and Laura McCann, "Library Collections Conservation Discussion Group 2008: Digitization Project Case Studies," Book \& Paper Group Annual 27 (2008): 116.

14. Gillian Boal, "Conservation for Digitization at the Wellcome Library,” Book \& Paper Group Annual 33 (2014): 12.

15. Patricia H. and Richard E. Garman Art Conservation Department, "Library and Archives Cohort," (Buffalo: Buffalo State, the State University of New York, 2017), accessed November 7, 2017, https://artconservation.buffalostate.edu /library-archives-cohort.

16. American Institute for Conservation, "AIC Wiki," (Washington, DC), accessed December 21, 2017, http://www. conservation-wiki.com/wiki/Main_Page.

17. Jennifer Hain Teper and Melissa Straw, "A Survey of Current Leather Conservation Practices," Book \& Paper Group Annual 30 (2011): 131-151.

18. Ann Carroll Kearney, "The Use of Japanese Paper as an Alternative Material in the Repair of Leather-Bound Items in Academic Research Libraries," Archival Products News 16, no. 4 (2011): 5-8.
19. Irene Alexopoulou and Spiros Zervos, "Paper Conservation Methods: An International Survey," Journal of Cultural Heritage 21, September (2016): 922-930.

20. Peterson, Robertson, and Szydlowski, "Do You Count?"

21. For examples, see: Andrea Pataki, "Remoistenable Tissue Preparation and its Practical Aspects," Restaurator 30 nos. 1-2 (2009): 51-69; Priscilla Anderson and Sarah Reidell, "Adhesive Pre-Coated Repair Materials," Book \& Paper Group Annual 28 (2009): 112-13; and Jody Beenk, Marieka Kaye, and Laura O'Brien Miller, “Archives Preservation Discussion Group," Book \& Paper Group Annual 28 (209): 99-106.

22. In the 2007 survey, categories 5 and 6 were combined into one section. In 2017, the sixteen treatments were separated into two groups of eight for more clearly defined categories and ease of survey response. The treatments in those categories are identical to those in 2007.

23. Baker and Dube, "Identifying Standard Practices in Research Library Book Conservation," 25.

24. When referring to "points" in the treatment practice sections, please note that "points" always refers to "percentage points."

25. Baker and Dube, "Identifying Standard Practices in Research Library Book Conservation,” 31.

\section{Appendix A: Survey Instrument}

\section{Book Conservation and Repair in Research Libraries}

\section{Introduction}

Your participation in this survey-"Book Conservation and Repair in Research Libraries"-will help document book current conservation treatment practices and trends in U.S. research libraries. Survey results will be widely disseminated, including a comparison of current practices with those captured in a similar survey ten years ago.

The survey should be completed by individuals performing or overseeing book conservation treatment or repair in research libraries. Appropriate to a respondent's job responsibilities, the questionnaire will inquire about special collections treatment, general collections treatment, or both.

Do you oversee and/or perform book conservation repair or treatment in a research library?

- Yes

- No

\section{Referral page}

If there is someone else at your institution who performs or oversees book conservation treatment please provide their names and email addresses:

\section{Survey Disclaimer}

Participation in the study entails completion of a questionnaire that should take approximately 15 minutes to complete. You will be asked whether you perform specific conservation treatments, and asked to provide some basic demographic information about yourself and your institution. We do not anticipate any risks to you from participating beyond than those encountered in daily life.

While there are no direct benefits to participating, information obtained from this study will enable library professionals to gain insight into current conservation treatment practices, including how they have evolved over the past ten years, a period which has seen significant change in the training of conservation professionals. Information gained from the study will be widely shared.

Your participation, while solicited and encouraged, is strictly voluntary, and you may discontinue at any time. Your name, should you chose the option to provide it, will never be associated in any way with the research findings. Completion of the survey indicates your willingness to participate in this research and that you are 18 years or older.

Should you have any questions about this survey, whether before or during the course of completing the 
questionnaire, please contact the survey administrator by phone or email. Thank you!

\section{Demographic Questions}

Institution size

- Fewer than 2 million volumes

- 2-3 million volumes

- 3-5 million volumes

- More than 5 million volumes

Institution type

- U.S. research library that is a member of ARL (Association of Research Libraries)

- U.S research library that is a member of the IRLA (Independent Research Libraries Association)

- Other U.S. institution:

Your job title:

What functions do you manage and/or participate in? (select all that apply)

- General collections book conservation/repair

- Special collections book conservation

What percentage of your position is dedicated to managing and/or participating in these activities?

- $75 \%$ or more

- $50-74 \%$

- $25-49 \%$

- Less than $25 \%$

Which best describes your institution's conservation/repair facilities?

- Our sole facility serves the general collections

- Our sole facility serves the special collections

- Our sole facility serves both special and general collections (may contain spaces, equipment and/or staff dedicated to special or general collections)

- We have separate/distinct facilities for special and general collections

- Other:

How recently was your in house conservation/repair facility built or last significantly renovated?

- $2010 \mathrm{~s}$

- $2000 \mathrm{~s}$

- 1990s

- 1980s

- Pre-1980

- N/A
How did you acquire your conservation knowledge and skills? (select all that apply)

- Conservation apprenticeship

- Graduate degree/certificate in conservation

- Bookbinding program with conservation component

- Graduate degree in Library/Information Science

- On the job training and/or experience

- Workshops/training sessions

- Professional association meetings

- Self study (e.g., books, online resources)

- Other:

Where did you receive your degree/certificate in conservation?

- Columbia/University of Texas at Austin

- Cooperstown/Buffalo

- Delaware/Winterthur

- NYU/IFA

- Camberwell College of Arts

- West Dean College

- Sorbonne

- Other

Which bookbinding program did you graduate from?

- North Bennet Street School

- American Academy of Bookbinding

- Other

\section{General/Special Collections Treatments}

(While otherwise identical, these two sections applied to general and special collections treatments, respectively. For treatments whose names were not self-explanatory, definitions were provided below the treatment in the survey tool. For ease of reading in this article they have been separated into a list; see appendix B.)

Considering the past three years, indicate which techniques are performed in house for general collections treatment, using the following categories:

Standard practice, frequent-Part of your established toolbox of techniques, executed routinely or with some regularity (relative to overall production levels).

Standard practice, occasional-Part of your established toolbox of techniques, executed occasionally or rarely (relative to overall production levels).

Anomalous - Performed rarely and for exceptional reasons. Not considered standard practice.

Never-Not used (in the past three years)

Not sure-Uncertain as to what this (and/or whether Ive used it in the past three years). 


\section{Protective Enclosures}

\begin{tabular}{|c|c|c|c|c|c|}
\hline & $\begin{array}{l}\text { Standard practice, } \\
\text { frequent }\end{array}$ & $\begin{array}{l}\text { Standard practice, } \\
\text { occasional }\end{array}$ & Anomalous use only & Never & Not sure \\
\hline \multicolumn{6}{|l|}{$\begin{array}{l}\text { Polyester book } \\
\text { jacket }\end{array}$} \\
\hline \multicolumn{6}{|l|}{$\begin{array}{l}\text { CoLibrì̀ }^{\mathrm{TM}} \\
\text { polyethylene book } \\
\text { jacket }\end{array}$} \\
\hline \multicolumn{6}{|l|}{$\begin{array}{l}3 \text { or 4-flap card } \\
\text { stock book wrapper } \\
\text { ("tuxedo" or variant } \\
\text { style) }\end{array}$} \\
\hline \multicolumn{6}{|l|}{$\begin{array}{l}\text { Cloth covered } \\
\text { clamshell book box }\end{array}$} \\
\hline \multicolumn{6}{|l|}{$\begin{array}{l}\text { Providing custom sized } \\
\text { book boxes purchased } \\
\text { from a vendor }\end{array}$} \\
\hline $\begin{array}{l}\text { Polyester sleeves and/ } \\
\text { or encapsulation }\end{array}$ & & & & & \\
\hline
\end{tabular}

\section{Binding Reinforcements}

\begin{tabular}{|l|l|l|l|l|l|}
\hline & $\begin{array}{l}\text { Standard Practice, } \\
\text { frequent }\end{array}$ & $\begin{array}{l}\text { Standard practice, } \\
\text { occasional }\end{array}$ & Anomalous use only & Never & Not sure \\
\hline $\begin{array}{l}\text { Pamphlet binding, } \\
\text { adhesive attachment }\end{array}$ & & & & \\
\hline $\begin{array}{l}\text { Pamphlet binding, } \\
\text { stapled }\end{array}$ & & & & \\
\hline $\begin{array}{l}\text { Pamphlet binding, } \\
\text { sewn }\end{array}$ & & & & & \\
\hline
\end{tabular}




\section{Minor Paper Treatments and Textblock Repairs}

\begin{tabular}{|c|c|c|c|c|c|}
\hline & $\begin{array}{l}\text { Standard practice, } \\
\text { frequent }\end{array}$ & $\begin{array}{l}\text { Standard practice, } \\
\text { occasional }\end{array}$ & Anomalous use only & Never & Not sure \\
\hline $\begin{array}{l}\text { Creating/inserting } \\
\text { photocopy } \\
\text { replacement pages }\end{array}$ & & & & & \\
\hline $\begin{array}{l}\text { Mending with } \\
\text { "archival" tape e.g., } \\
\text { Filmoplast, Archival } \\
\text { Aids }\end{array}$ & & & & & \\
\hline $\begin{array}{l}\text { Mending with heat set } \\
\text { tissue }\end{array}$ & & & & & \\
\hline $\begin{array}{l}\text { Mending with } \\
\text { remoistenable/solvent- } \\
\text { set tissue }\end{array}$ & & & & & \\
\hline $\begin{array}{l}\text { Mending with } \\
\text { Japanese paper \& } \\
\text { paste }\end{array}$ & & & & & \\
\hline $\begin{array}{l}\text { Guarding sections } \\
\text { with Japanese paper } \\
\text { \& paste }\end{array}$ & & & & & \\
\hline $\begin{array}{l}\text { Toning Japanese paper } \\
\text { for mends and/or fills }\end{array}$ & & & & & \\
\hline $\begin{array}{l}\text { Re-sewing several } \\
\text { sections }\end{array}$ & & & & & \\
\hline $\begin{array}{l}\text { (Re)sewing an entire } \\
\text { volume }\end{array}$ & & & & & \\
\hline $\begin{array}{l}\text { Barrier spine lining of } \\
\text { Japanese paper and } \\
\text { paste }\end{array}$ & & & & & \\
\hline $\begin{array}{l}\text { New end sheets, } \\
\text { tipped on }\end{array}$ & & & & & \\
\hline $\begin{array}{l}\text { New endsheets, } \\
\text { hinged onto the spine } \\
\text { with Japanese paper }\end{array}$ & & & & & \\
\hline $\begin{array}{l}\text { New end sheets, sewn } \\
\text { on }\end{array}$ & & & & & \\
\hline Adhesive binding & & & & & \\
\hline
\end{tabular}




\section{Board Reattachment Methods}

\begin{tabular}{|l|l|l|l|l|l|}
\hline & $\begin{array}{l}\text { Standard practice, } \\
\text { frequent }\end{array}$ & $\begin{array}{l}\text { Standard practice } \\
\text { occasional }\end{array}$ & Anomalous use only & Never & Not sure \\
\hline Joint tacketing & & & & & \\
\hline $\begin{array}{l}\text { Japanese paper board } \\
\text { reattachment }\end{array}$ & & & & \\
\hline $\begin{array}{l}\text { Toning Japanese paper } \\
\text { with acrylics for board } \\
\text { reattachment }\end{array}$ & & & & \\
\hline $\begin{array}{l}\text { Solvent set tissue } \\
\text { board reattachment }\end{array}$ & & & & \\
\hline Board slotting & & & & & \\
\hline Partial cloth hinge & & & & & \\
\hline New slips & & & & \\
\hline
\end{tabular}

Rebinding Styles

\begin{tabular}{|l|l|l|l|l|l|}
\hline & $\begin{array}{l}\text { Standard practice, } \\
\text { frequent }\end{array}$ & $\begin{array}{l}\text { Standard practice, } \\
\text { occasional }\end{array}$ & Anomalous use only & Never & Not sure \\
\hline Recase & & & & & \\
\hline New case & & & & & \\
\hline $\begin{array}{l}\text { Lapped case/Bradel } \\
\text { binding }\end{array}$ & & & & & \\
\hline $\begin{array}{l}\text { New limp vellum and/ } \\
\text { or limp paper case } \\
\text { binding }\end{array}$ & & & & & \\
\hline Sewn boards binding & & & & & \\
\hline Split board binding & & & & & \\
\hline Treatment 305 & & & & & \\
\hline $\begin{array}{l}\text { Double-fan adhesive } \\
\text { binding }\end{array}$ & & & & \\
\hline
\end{tabular}




\section{Binding Repair Techniques}

\begin{tabular}{|c|c|c|c|c|c|}
\hline & $\begin{array}{l}\text { Standard practice, } \\
\text { frequent }\end{array}$ & $\begin{array}{l}\text { Standard practice, } \\
\text { occasional }\end{array}$ & Anomalous use only & Never & Not sure \\
\hline \multicolumn{6}{|l|}{ Cloth reback } \\
\hline Japanese paper reback & & & & & \\
\hline $\begin{array}{l}\text { Reattaching detached } \\
\text { spines with a hollow } \\
\text { tube or v-hinge }\end{array}$ & & & & & \\
\hline $\begin{array}{l}\text { Lifting endsheets } \\
\text { to save original } \\
\text { pastedown endsheets }\end{array}$ & & & & & \\
\hline $\begin{array}{l}\text { Dyeing cloth with } \\
\text { acrylics for binding } \\
\text { repairs }\end{array}$ & & & & & \\
\hline $\begin{array}{l}\text { Consolidating leather } \\
\text { with Klucel-G }\end{array}$ & & & & & \\
\hline
\end{tabular}

Advanced Paper Treatments Performed on Books/Bound Volumes

\begin{tabular}{|l|l|l|l|l|l|}
\hline & $\begin{array}{l}\text { Standard practice, } \\
\text { frequent }\end{array}$ & $\begin{array}{l}\text { Standard practice, } \\
\text { occasional }\end{array}$ & Anomalous use only & Never & Not sure \\
\hline $\begin{array}{l}\text { Aqueous washing/ } \\
\text { alkalization }\end{array}$ & & & & & \\
\hline $\begin{array}{l}\text { Bookkeeper } \\
\text { deacidification } \\
\text { (in-house) }\end{array}$ & & & & \\
\hline $\begin{array}{l}\text { Tape/adhesive removal } \\
\text { using heat }\end{array}$ & & & & \\
\hline $\begin{array}{l}\text { Tape/adhesive/stain } \\
\text { removal using water } \\
\text { (e.g., methyl cellulose) }\end{array}$ & & & & & \\
\hline $\begin{array}{l}\text { Tape/adhesive/stain } \\
\text { removal using other } \\
\text { solvents }\end{array}$ & & & & & \\
\hline $\begin{array}{l}\text { Dry cleaning with } \\
\text { vinyl erasers and/or } \\
\text { vinyl eraser crumbs }\end{array}$ & & & & & \\
\hline
\end{tabular}

Other/Notes: 


\section{Conclusion}

Would you be willing to participate in a brief follow up survey in a couple of months, if needed?

- Yes

- No
Your name:

Your email address:

Thank you! Your survey has been submitted. Thank you for your participation.

\section{Appendix B: Treatment Names and Definitions}

The survey included the following definitions for treatments whose names were deemed insufficiently self-explanatory. The definitions were listed below corresponding treatments in the survey tool but are listed separately here for clarity.

\section{Treatment Name}

Polyester book jacket

CoLibrì ${ }^{\mathrm{TM}}$ polyethylene book jacket

Polyester sleeves and/or encapsulation

Mending with heat-set tissue

Joint tacketing

Japanese paper board reattachment

Solvent-set tissue board reattachment

Board slotting

Partial cloth hinge

New slips

Recase

New case

Lapped case/Bradel binding

New limp vellum or limp paper case binding

Sewn boards binding

Split board binding

Treatment 305

Cloth reback

Leather reback

Japanese paper reback

Aqueous washing/alkalization

BookkeeperTM deacidification (in-house)

\section{Definition}

Non-adhesive custom-fitted book jacket made of clear polyester film (e.g., Mylar).

Machine-assisted method for fitting books with non-adhesive polyethylene book jackets.

Encapsulating paper in polyester (e.g., Mylar) and/or using prefabricated polyester sleeves (where one or more edges may remain unsealed).

A thin, acrylic-coated tissue applied with a heated tool.

Board reattachment technique wherein thread is laced through holes piercing the book's shoulder and through corresponding holes in the boards.

Board reattachment technique wherein Japanese paper is adhered along the inner (and typically also the outer) joint.

Variant Japanese paper board reattachment technique employing solvent-set tissue impregnated with an adhesive.

Board reattachment technique employing specialized equipment to create an angled slot in the edge of the board for a cloth spine lining hinge.

Board reattachment technique that minimizes spine disruption by employing limited sections of cloth spine linings/hinges, typically at the head and tail.

Using new thread (or cords or tapes) to extend sewing supports and create new board attachment slips at one or more sewing station.

Rebinding using the original case binding.

Rebinding using a newly constructed case binding (may include retaining parts of the original cloth, such as onlaying the original spine title).

Variant case binding in which the boards are attached to each other with cloth or paper, creating a "flexible spine inlay" prior to covering.

Generally non-adhesive limp paper/parchment cover with a textblock typically sewn on supports that are laced into the cover.

Early coptic adaptation in which the boards, typically folios of mat board, are sewn with the textblock. Cloth/paper coverings use minimal adhesive.

In-boards binding repair in which new boards are constructed as laminates, with the hinge and sewing supports sandwiched between layers of board.

Tight joint repair in which new boards are attached with a cloth spine lining adhered to (and sometimes inset in) the outside of the boards. The covering may be dyed to approximate leather.

Spine replacement using new cloth.

Spine replacement using new leather.

Spine replacement using Japanese paper.

Removing acidic products by bathing paper in water. Alkaline chemicals may be employed to deposit an alkaline reserve in the paper

A commercial product sprayed onto paper to slow acidic degradation processes. 